\title{
FAKTOR-FAKTOR YANG MEMPENGARUHI MINAT MASYARAKAT MENGAJUKAN KREDIT DI FINANCIAL TECHNOLOGY (FINTECH)
}

\author{
${ }^{1}$ Aulia, ${ }^{2}$ Zulkarnaini, ${ }^{3}$ Early Ridho Kismawadi
}

\begin{abstract}
ABSTRAK
Tujuan penelitian ini adalah untuk mengetahui bagaimana kemudahan penggunaan, efektivitas dan resiko mempengaruhi minat masyarakat mengajukan kredit di Fintech. Jenis penelitian yang digunakan adalah kuantitatif. Teknik pengumpulan data yang digunakan adalah angket. Populasi dalam penelitian ini adalah seluruh masyarakat yang ada di Kabupaten Aceh Tamiang. Teknik sampling yang digunakan adalah teknik Quota Sampling dengan jumlah 75 orang. Teknik analisis data menggunakan uji asumsi klasik, uji regresi linear berganda, uji hipotesis dan uji koefisien determinasi. Hasil penelitian menunjukkan bahwa secara parsial kemudahan penggunaan berpengaruh positif dan signifikan terhadap minat masyarakat mengajukan kredit di Fintech dengan nilai $\mathrm{t}$ hitung 2,506 > 1,993 (t tabel) dan nilai sig $0.003<0.05$. Secara parsial efektivitas berpengaruh positif dan signifikan terhadap minat masyarakat mengjukan kredit di Fintech dengan nilai $t$ hitung 3,603 > 1,993 (t tabel) dan nilai sig $0.002<0.05$. Secara parsial resiko berpengaruh positif dan signifikan terhadap minat masyarakat mengajukan kredit di Fintech dengan nilai t hitung 2,296 >1,993 (t tabel) dan nilai $0.004<0.05$. Secara simultan kemudahan penggunaan, efektivitas dan resiko secara simultan berpengaruh terhadap positif dan signifikan terhadap minat masyarakat mengajukan kredit di Fintech. Hal ini dibuktikan dari nilai F hitung > F tabel $(4,192>$ 3,12 ) dan nilai signifikan sebesar 0,000 , maka sebagaimana dasar pengambilan keputusan dalam uji $\mathrm{F}$ dapat disimpulkan bahwa hipotesis diterima.

Kata Kunci: Kemudahan Penggunaan, Efektivitas, Resiko dan Minat Masyarakat mengajukan Kredit di Fintech.
\end{abstract}

\begin{abstract}
The purpose of this study was to find out how ease of use, effectiveness and risk affected people's interest in applying for dibfintech loans. The type of research used is quantitative. Data collection techniques used were questionnaires. The population in this study is the entire community in the district of Aceh Tamiang. The sampling technique used was a quota sampling technique with a total of 75 people. Data analysis techniques using the classic assumption test, multiple linear regression test, hypothesis testing and coefficient of determination test. The results showed that partial ease of use had a positive and significant effect on people's interest in applying for credit at fintech with a value of $t$ arithmetic 2,506 > 1,993 ( $t$ table) and sig value 0,003 < 0,05. Partially the effectiveness is positive and significant effect on people's interest in applying for credit in fintech with a calculated exchange rate of 3,603 > 1,993 ( $t$ table) and a sig value of 0,002 <0,05. Partially the risk of positive and significant effect on people's interest in applying for credit in fintech with a value of $t$ arithmetic 2,296 > 1,993 ( $t$ table) and a sig value of 0,004 < 0,05. Simultaneously the ease of use, effectiveness and risk have a positive and significant impact on people's interest in appying for credit at fintech. This is evidenced by the calculated $F$ value $>F$ table $(4,192>3,12)$ and a
\end{abstract}

${ }^{1}$ Fakultas Ekonomi dan Bisnis Islam IAIN Langsa, aulia111@gmail.com

${ }^{2}$ Fakultas Ekonomi dan Bisnisn Islam IAIN Langsa

${ }^{3}$ Fakultas Ekonomi dan Bisnisn Islam IAIN Langsa 
significant value of 0,000, then as the basis for decision making in the F test it can be concluded that the hypothesis is accepted.

Keywords: Ease of use, effectiveness, risk and community interest in applying for credit at fintech

\section{PENDAHULUAN}

Perkembangan teknologi digital dewasa ini sangatlah pesat, banyak inovasiinovasi baru yang bermunculan dibidang teknologi digital mulai dari software hingga hardware serta perangkat pendukung lainnya. Perkembangan teknologi digital juga didukung dengan penggunaan gadget dan Internet yang juga mengalami peningkatan, anak-anak hingga orang dewasapun menggunakannya. Menurut hasil survei yang dilakukan oleh Asosiasi Penyelenggara Jasa Internet Indonesia (APJII) bahwa pengguna Internet di Indonesia sebanyak 143,26 juta jiwa atau sebesar 54,68\% dari total penduduk indonesia adalah penggunaan Internet.

Perkembangan teknologi digital sekarang sudah merambah hampir seluruh aspek kehidupan mulai dari berbelanja, transportasi, keuangan, pariwisata hingga memberikan donasi serta kegiatan ekonomi lainnya dapat diakses secara digital. Perkembangan Teknologi digital telah mengubah gaya hidup masyarakat masa kini, kehidupan masyarakat yang dekat dengan gadget dan Internet dan di dukung dengan fasilitas pelayanan yang berbasis teknologi digital membuat aktivitas sehari-hari masyarakat menjadi lebih sederhana dengan menggunakan gadget dalam genggaman tangan mereka. Hal ini mendorong perkembangan bisnis berbasis teknologi digital, salah satunya adalah Financial Technology (Fintech).

Fintech adalah sebuah sistem keuangan berbasis teknologi yang menghasilkan produk, layanan, teknologi atau model bisnis baru yang berdampak pada kestabilan moneter, kestabilan sistem keuangan atau efisiensi, kelancaran, keamanan serta keandalan dalam sistem pembayaran.

Jumlah Fintech yang terdaftar dan berizin di OJK sebanyak 144 perusahaan. Adapun pihak yang berwenang dalam mengatur operasional Fintech adalah Bank Indonesia (BI), Otoritas Jasa Keuangan (OJK), dan Kementrian Komunikasi dan Informasi (KEMKOMINFO). Regulasi dari pihak berwenang sangat bermanfaat bagi konsumen sehingga hak- hak konsumen dapat terlindungi sehingga konsumen mendapat kenyamanan saat bertransaksi. Berikut ini adalah diagram akumulasi penyaluran dana pinjaman fintech dari tahun 2018 hingga 2020 berdasarkan data OJK (Otoritas Jasa Keuangan). 


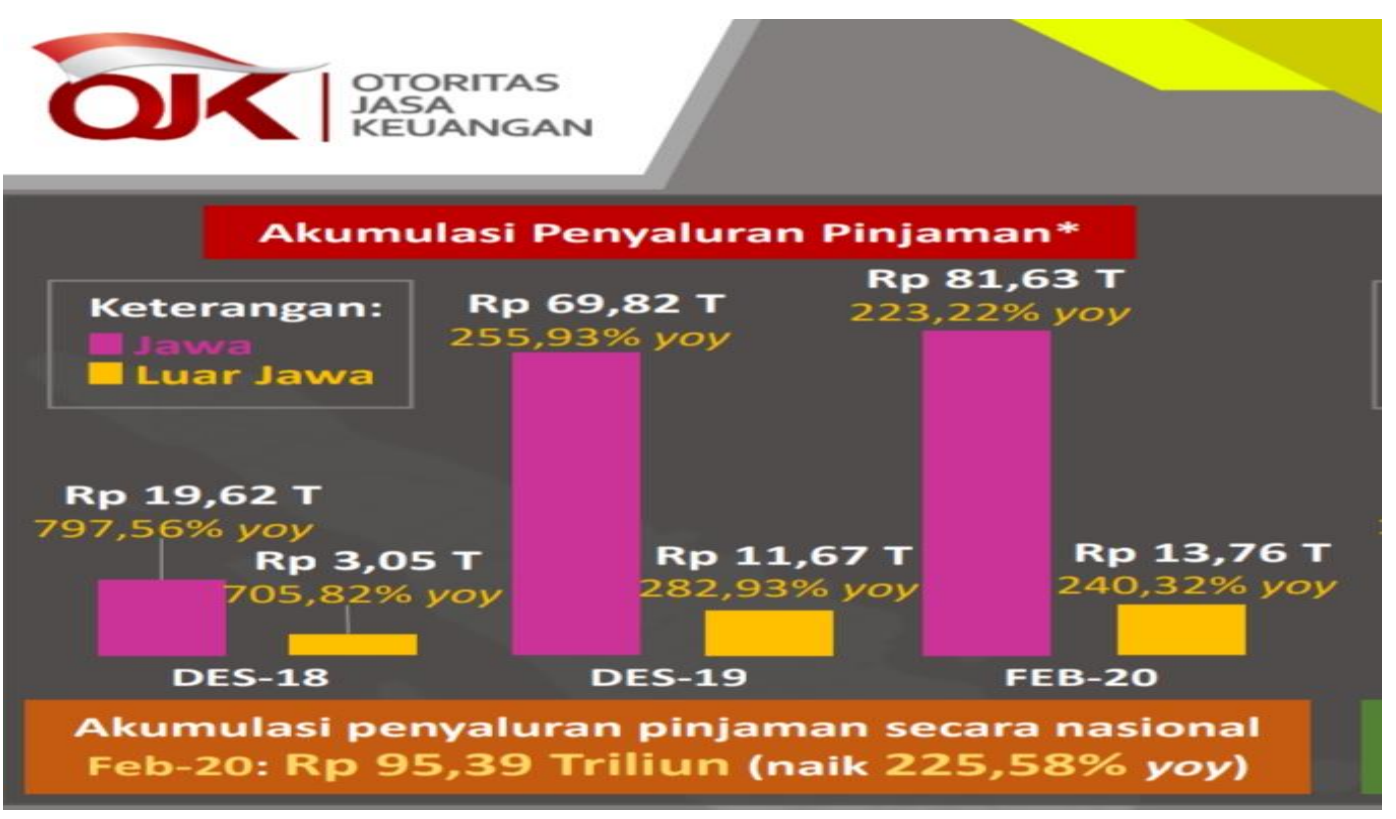

Sumber: www.ojk.go.id, Diakses Pada 18 April 2020.

Dalam meningkatkan minat masyarakat dalam mengajukan kredit di Fintech, perusahaan Fintech harus mengetahui dan memahami faktor-faktor yang mempengaruhi minat masyarakat dalam mengajukan kredit yaitu salah satunya tentang kemudahan penggunaan. Kemudahan penggunaan adalah suatu anggapan individu bahwa dengan menggunakan teknologi maka tidak akan mengeluarkan usaha yang lebih atau dengan kata lain bahwa menggunakan teknologi dapat mempermudah pekerjaannya.

Seharusnya, setiap teknologi diciptakan guna mempermudah aktivitas setiap individu, semakin mudah teknologi, maka individu semakin berminat untuk menggunakannya. Namun nyatanya berdasarkan hasil wawancara peneliti dengan beberapa masyarakat di Kabupaten Aceh Tamiang diketahui bahwa pengguna produk Fintech merasa kesulitan dalam menggunakan aplikasi dari produk Fintech, meskipun dalam aplikasi produk Fintech telah dilengkapi dengan tata cara penggunaannya. Hal ini juga yang menjadi alasan dari masyarakat Kabupaten Aceh Tamiang yang belum menggunakan produk Fintech, karena dianggap bertransaksi menggunakan Fintech lebih sulit dari bertransaksi secara langsung. Hal ini bukan tanpa alasan, masyarakat di Kabupaten Aceh Tamiang cenderung tidak mengoptimalkan fungsi dari smartphone atau gadget yang dimilikinya, kebanyakan smartphone masyarakat di Kabupaten Aceh Tamiang digunakan untuk mengkases social media, game dan aplikasi hiburan lainnya. Seperti yang kita ketahui banyak aplikasi yang bermanfaat bagi kehidupan sehari- hari namun jarang sekali digunakan oleh masyarakat, seperti Microsoft Office, G-mail, Note dan lain-lain. Seharusnya penggunaan teknologi perlu dibiasakan sehingga ketika ada inovasi baru kita sebagai pengguna sudah terbiasa dengan kehidupan digital dan tidak mengalami kesulitan terhadap pengoperasiannya

Efektivitas dalam kamus bahasa Indonesia berasal dari kata efektif yang berarti pengaruh, efek atau dapat membawa hasil. Dalam konteks penelitian ini efektivitas berarti hasil yang didapat dari penggunaan teknologi yang sesuai dengan tujuan pengguna. Seharusnya penggunaan teknologi yang sesuai dengan tujuan pengguna sangat membantu masyarakat dalam memudahkan segala usrusan dan pekerjaannya. Namun nyatanya berdasarkan hasil wawancara dengan beberapa masyarakat di 
Kabupaten Aceh Tamiang yang menggunakan Fintech diketahui bahwa masyarakat pengguna produk Fintech tidak begitu terbantu dari penggunaan aplikasi dari produk Fintech, karena di lingkungan Kabupaten Aceh Tamiang belum banyak yang menggunakan produk Fintech.

Risiko merupakan suatu ketidakpastian yang dirasakan oleh pengguna yang menimbulkan kerugian kepada pengguna. Risiko yang awal dirasakan oleh pengguna adalah risiko kejahatan cyber (cyber risk). (Nizar, 2017) Kejahatan cyber dapat mengancam setiap transaksi yang dilakukan konsumen, keamanan data pribadi setiap pengguna juga tidak luput dari ancaman kejahatan cyber. Kebocoran data pribadi dan penyalahgunaan data dapat merugikan pengguna.

Seharusnya bisnis Fintech merupakan bisnis kepercayaan antara pengguna dan pengembang, jika terjadi sebuah kebocoran data, penyalah gunaan data, pemalsuan data dan lain sebagainya sama saja menciderai kepercayaan antara pengguna dan pengembang dan sebaliknya. Kepercayaan sangatlah penting dalam hal ini, dimana pengguna dan pengembang Fintech tidak dipertemukan secara langsung, karena penggunaan Fintech dilakukan dengan jarak jauh. Adanya berbagai risiko yang berpotensi merugikan pengguna dan pihak pengembang sendiri seharusnya pengembang Fintech dapat meningkatkan keamanan dari sistem yang dimilikinya, serta memberikan edukasi terhadap calon pengguna sehingga dapat meminimalisir terjadinya kesalahan yang merugikan pengguna, karena penggunaan Fintech dilakukan secara mandiri oleh penggunanya. Setiap risiko tentunya dapat diminimalisir dengan kebijakan-kebijakan yang saling menguntungkan antara kedua belah pihak sehingga tidak menimbulkan kerugian-kerugian yang berarti diantara kedua belah pihak.

Namun nyatanya, sebagian masyarakat pengguna Fintech di Kabupaten Aceh Tamiang yang telah menggunakan produk Fintech tidak terlalu mengahawatirkan risiko yang ada dalam penggunaan produk Fintech. Mereka tetap akan menggunakan produk Fintech meskipun berisiko.

Berdasarkan latar belakang di atas, maka peneliti tertarik melakukan penelitian dengan judul "Faktor-Faktor yang Mempengaruhi Minat Masyarakat Mengajukan Kredit di Financial Technology (FINTECH)". Berdasarkan latar belakang masalah di atas, permasalahan dalam penelitian ini adalah sebagai berikut:

1. Bagaimana kemudahan penggunaan mempengaruhi minat masyarakat mengajukan kredit di Fintech?

2. Bagaimana efektivitas mempengaruhi minat masyarakat mengajukan kredit di Fintech?

3. Bagaimana resiko mempengaruhi minat masyarakat mengajukan kredit di Fintech?

4. Bagaimana kemudahan penggunaan, efektivitas dan resiko secara simultan mempengaruhi minat masyarakat mengajukan kredit di Fintech?

\section{Metode Penelitian}

Jenis peneleitian ini adalah penelitian kuantitatif. Penelitian kuantitatif adalah penelitian yang berdasarkan data-data yang bersifat angka-angka statistik yang dapat dikuantifikasi yang digunakan untuk meneliti objek, populasi/sampel tertentu, pengumpulan data menggunakan instrumen penelitian, analisis data bersifat kuantitatif/statistik dengan tujuan untuk menguji hipotesis yang ditetapkan. Proses penelitian mengikuti prosedur yang telah direncanakan, data yang dikumpulkan dan 
sumber data yang dibutuhkan serta alat pengumpul data yang dipakai sesuai dengan apa yang telah direncanakan sebelumnya. (Sugiono, 2010).

\section{Metode Pengumpulan Data}

Metode pengumpulan data yang digunakan adalah metode kuesioner (angket). Metode kuesioner yaitu sejumlah pertanyaan tertulis untuk memperoleh informasi dari responden.

\section{Metode Analisis Data}

Teknik analisis data yang digunakan dalam penelitian ini adalah statistik deskriptif, yaitu statistik yang digunakan untuk menganalisa data dengan cara mendeskripsikan atau menggambarkan data yang telah terkumpul sebagaimana adanya tanpa bermaksud untuk membuat kesimpulan yang berlaku untuk umum atau generalisasi. (Sugiono, 2010).

\section{Uji Asumsi Klasik}

Adapun uji asumsi klasik yang digunakan dalam penelitian ini adalah uji normalitas, uji linearitas, uji multikollinearitas, uji heteroskedastisitas dan uji autokorelasi.

\section{a. Uji Normalitas}

Uji normalitas yang dilakukan pada penelitian ini bertujuan untuk menguji apakah dalam model regresivariabel independen dan variabel dependen memiliki distribusi normal atau tidak.

\section{b. Uji Linearitas}

Uji linearitas dilakukan untuk mengetahui apakah antara variabel bebas dan variabel terikat mempunyai linear atau tidak. Dengan ketentuan jika koefisien signifikansi > 0,05 maka dapat dinyatakan bahwa garis regresi berbentuk linear.

\section{c. Uji Multikolinieritas}

Pengujian ini bertujuan untuk mengetahui apakah tiap-tiap variabel saling berhubungan secara linear.

\section{d. Uji Heteroskedastisitas}

Dalam penelitian ini, pengujian heteroskedastisitas bertujuan untuk menguji apakah dalam model regresi terjadi ketidaksamaan variance dari residual satu pengamatan kepengamatan yang lain.

\section{e. Uji Autokorelasi}

Uji autokorelasi merupakan bagian dari uji asumsi klasik (normalitas, multikolinearitas, linearitas dan heteroskedastisitas) dalam analisis regresi linear sederhana maupun berganda.

\section{Uji Regresi Linear Berganda}

Analisis data yang digunakan adalah regresi linear berganda. Analisis regresi linear berganda merupakan sebuah teknik yang bertujuan untuk mengetahui hubungan dari beberapa variabel bebas dan beberapa variabel terikat. Adapun analisis regresi linier berganda digunakan dengan rumus: (Magda, 2017).

$$
\mathrm{Y}=\mathrm{a}+\mathrm{b} 1 \mathrm{X} 1+\mathrm{b} 2 \mathrm{X} 2+\mathrm{b} 3 \mathrm{X} 3+\mathrm{et}
$$

Keterangan :

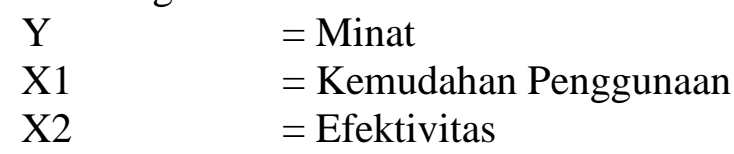




$$
\begin{aligned}
& \text { X3 = Resiko } \\
& \text { a } \quad=\text { Konstanta } \\
& \text { b1, b2 ,b3= Koefisien Regresi } \\
& \text { et } \quad=\text { Error Term }
\end{aligned}
$$

\section{Uji Hipotesis}

a. Uji t (Uji Parsial)

Uji parsial digunakan untuk menunjukkan sebarapa jauh satu variabel independen secara individu dalam menerangkan variasi variabel dependen.

\section{b. Uji F Simultan}

Uji F (Simultan) digunakan untuk menunjukkan apakah semua variabel independen yang dimasukkan dalam model mempunyai pengaruh secara bersama-sama terhadap variabel dependen.

\section{c. Uji Koefisien Determinasi}

Uji Koefisien Determinasi $\left(\mathrm{R}^{2}\right)$ pada intinya mengukur seberapa jauh kemampuan model dalam menerangkan variasi variabel terikat.

\section{HASIL DAN PEMBAHASAN}

\section{A. Uji Pra syarat}

\section{Uji Validitas}

Uji validitas dilakukan untuk mengetahui bahwa setiap butir pertanyaan dan pernyataan yang diajukan kepada responden telah dinyatakan valid atau tidak valid. Untuk menentukan valid atau tidaknya suatu item, maka apabila perbandingan antara $\mathrm{r}_{\text {hitung }}>\mathrm{r}_{\text {tabel }}$ dengan taraf signifikan sebesar 5\% atau 0,05, maka suatu item soal dinyatakan valid. Penelitian ini menggunakan $\mathrm{N}=75$, dimana 75-2 $=73$, sehingga didapat $r$ tabel $=0,227$.

Untuk mengetahui tingkat validitas daris etiap pertanyaan pada kuesioner, maka dilakukan terlebih dahulu perhitungan statistic dengan menggunakan program SPSS 22.0. Adapun hasil perhitungan uji validitas diperoleh hasil pada tabel di bawah ini:

Tabel Validitas

\begin{tabular}{|c|c|c|c|}
\hline No. Butir & r hitung & r tabel & Keterangan \\
\hline \multicolumn{4}{|c|}{ Kemudahan Penggunaan $\left(\mathbf{X}_{\mathbf{1}}\right)$} \\
\hline Kemudahan Penggunaan 1.1 & 0,517 & 0,227 & Valid \\
\hline Kemudahan Penggunaan 1.2 & 0,501 & 0,227 & Valid \\
\hline Kemudahan Penggunaan 1.3 & 0,722 & 0,227 & Valid \\
\hline Kemudahan Penggunaan 1.4 & 0,728 & 0,227 & Valid \\
\hline Kemudahan Penggunaan 1.5 & 0,620 & 0,227 & Valid \\
\hline No. Butir & r hitung & r tabel & Keterangan \\
\hline \multicolumn{4}{|c|}{ Efektivitas $\left(\mathbf{X}_{2}\right)$} \\
\hline Efektivitas 2.1 & 0,396 & 0,227 & Valid \\
\hline Efektivitas 2.2 & 0,569 & 0,227 & Valid \\
\hline Efektivitas 2.3 & 0,756 & 0,227 & Valid \\
\hline Efektivitas 2.4 & 0,890 & 0,227 & Valid \\
\hline Efektivitas 2.5 & 0,747 & 0,227 & Valid \\
\hline
\end{tabular}




\begin{tabular}{|c|c|c|c|}
\hline No. Butir & r hitung & r tabel & Keterangan \\
\hline \multicolumn{4}{|c|}{ Resiko $\left(\mathbf{X}_{3}\right)$} \\
\hline \multicolumn{4}{|c|}{} \\
\hline Resiko 3.1 & 0,717 & 0,227 & Valid \\
\hline Resiko 3.2 & 0,842 & 0,227 & Valid \\
\hline Resiko 3.3 & 0,846 & 0,227 & Valid \\
\hline Resiko 3.4 & 0,864 & 0,227 & Valid \\
\hline Resiko 3.5 & 0,766 & 0,227 & Valid \\
\hline No. Butir & r hitung & r tabel & Keterangan \\
\hline \multicolumn{4}{|c|}{ Minat $(Y)$} \\
\hline Minat 1.1 & 0,426 & 0,227 & Valid \\
\hline Minat 1.2 & 0,463 & 0,227 & Valid \\
\hline Minat 1.3 & 0,650 & 0,227 & Valid \\
\hline Minat 1.4 & 0,572 & 0,227 & Valid \\
\hline Minat 1.5 & 0,682 & 0,227 & Valid \\
\hline
\end{tabular}

Sumber : Data primer diolah, 2020

Berdasarkan Tabel di atas, diketahui bahwa nilai koefisien korelasi seluruhnya memiliki $r_{\text {hitung }}>r_{\text {tabel }}\left(r_{\text {tabel }}=0,227\right)$. Sehingga dapat disimpulkan bahwa semua butir pertanyaan dan pernyataan pada instrumen tentang kemudahan penggunaan (X1), efektivitas (X2) dan resiko (X3) terhadap minat masyarakat mengajukan kredit di fintech (Y) dapat dinyatakan valid dan layak sebagai instrumen untuk mengukur penelitian.

\section{Uji Reliabilitas}

Suatu kuesioner dikatakan reliabel/handal jika jawaban seseorang terhadap pernyataan adalah konsisten atau stabil dari waktu kewaktu. Dengan ketentuan jika memberikan nilai Cronbach Alpha $=>0,60$, maka suatu kontruk atau variabel dikatakan reliabel. Tabel di bawah ini menunjukkan hasil pengujian reliabilitas dengan menggunakan SPSS versi 22,0.

\begin{tabular}{|l|c|c|c|}
\multicolumn{1}{|c|}{ Tabel Reliabilitas } \\
\hline & $\begin{array}{c}\text { Cronbach } \\
\text { Alpha }\end{array}$ & $\begin{array}{c}\text { Batas } \\
\text { Keandalan }\end{array}$ & Keterangan \\
\hline Kemudahan Penguunaan $\left(\mathrm{X}_{1}\right)$ & 0,635 & 0,60 & Reliabel \\
\hline Efektivitas $\left(\mathrm{X}_{2}\right)$ & 0,769 & 0,60 & Reliabel \\
\hline Resiko $\left(\mathrm{X}_{3}\right)$ & 0,808 & 0,60 & Reliabel \\
\hline Minat $(\mathrm{Y})$ & 0,713 & 0,60 & Reliabel \\
\hline
\end{tabular}

Sumber: Data Primer diolah, 2020

Berdasarkan Tabel di atas, dapat diketahui bahwa semua item (pertanyaan/soal) yang terdapat dalam kuesioner tentang variabel kemudahan penggunaan (X1), efektivitas (X2) dan resiko (X3) terhadap minat masyarakat mengajukan kredit di Fintech dinyatakan raliabel/handal, karena memiliki nilai Cronbach Alpha >0,6. 


\section{B. Uji Asumsi Klasik}

\section{Uji Multikolinieritas}

Uji ini dilakukan untuk mengetahui ada tidaknya korelasi antar variabel bebas dalam penelitian. Model regresi yang baik seharusnya tidak terjadi korelasi antara variabel bebas. Untuk mendeteksi ada tidaknya multikolinieritas dapat dilihat pada nilai tolerance dan VIF. Apabila nilai tolerance di atas 0,1 dan nilai VIF dibawah 10 maka tidak terjadi multikolinieritas.

Tabel Hasil Uji Multikolinieritas

\begin{tabular}{|c|c|c|c|c|c|c|c|c|}
\hline \multirow{2}{*}{\multicolumn{2}{|c|}{ Model }} & \multicolumn{2}{|c|}{$\begin{array}{c}\text { Unstandardized } \\
\text { Coefficients }\end{array}$} & \multirow{2}{*}{$\begin{array}{c}\text { Standardized } \\
\text { Coefficients }\end{array}$} & \multirow[b]{2}{*}{$\mathrm{T}$} & \multirow[b]{2}{*}{ Sig. } & \multicolumn{2}{|c|}{ Collinearity Statistics } \\
\hline & & B & Std. Error & & & & Tolerance & VIF \\
\hline \multirow[t]{4}{*}{1} & (Constant) & 12,423 & 3,416 & & 3,636 &, 001 & & \\
\hline & $\begin{array}{l}\text { Kemudahan_Pe } \\
\text { nggunaan }\end{array}$ & ,138 & ,124 &, 160 & 1,115 &, 271 & ,995 & 1,005 \\
\hline & Efektivitas & ,233 & ,122 &, 158 & 1,094 & ,280 & ,979 & 1,021 \\
\hline & Resiko &, 115 &, 079 &, 210 & 2,068 & ,946 & ,984 & 1,016 \\
\hline
\end{tabular}

Berdasarkan Tabel di atas yaitu tabel output "Coefficients" pada bagian Collinearity Statistics diketahui nilai Tolerance untuk variabel kemudahan penggunaan (X1) adalah 0,995, untuk variabel efektivitas (X2) adalah 0,979 dan untuk variabel resiko (X3) adalah 0,984. Maka diketahui nilai tolerance dari ketiga variabel kemudahan penggunaan, efektivitas dan resiko lebih besar dari 0,10. Sedangkan nilai VIF pada variabel kemudahan penggunaan (x1) adalah 1,005, nilai VIF dari variabel efektivitas (X2) adalah 1,021 dan nilai VIF dari variabel resiko adalah 1,016. Karena nilai tolerance dari ketiga variabel penelitian $>0,10$ dan nilai VIF dari ketiga variabel penelitian $<10,00$, maka dapat disimpulkan bahwa tidak terjadi gejala multikolinearitas dalam model regresi ini.

\section{Uji Heteroskedastisitas}

Pengujian ini bertujuan untuk menguji apakah dalam model regresi terjadi ketidaksamaan variance dari residual satu pengamatan kepengamatan yang lain. Dalam hal ini, model regresi yang baik adalah yang tidak terjadi heteroskedastisitas. Untuk mengetahui ada tidaknya heteroskedastisitas yaitu dengan menggunakan metode scatterplot. Jika titik-titik pada grafik scatterplot tidak membentuk suatu pola tertentu, maka asumsi heterokedastisitas terpenuhi. Berikut adalah hasil dari grafik scatterplot.

\section{Gambar Hasil Uji Heteroskedastisitas}

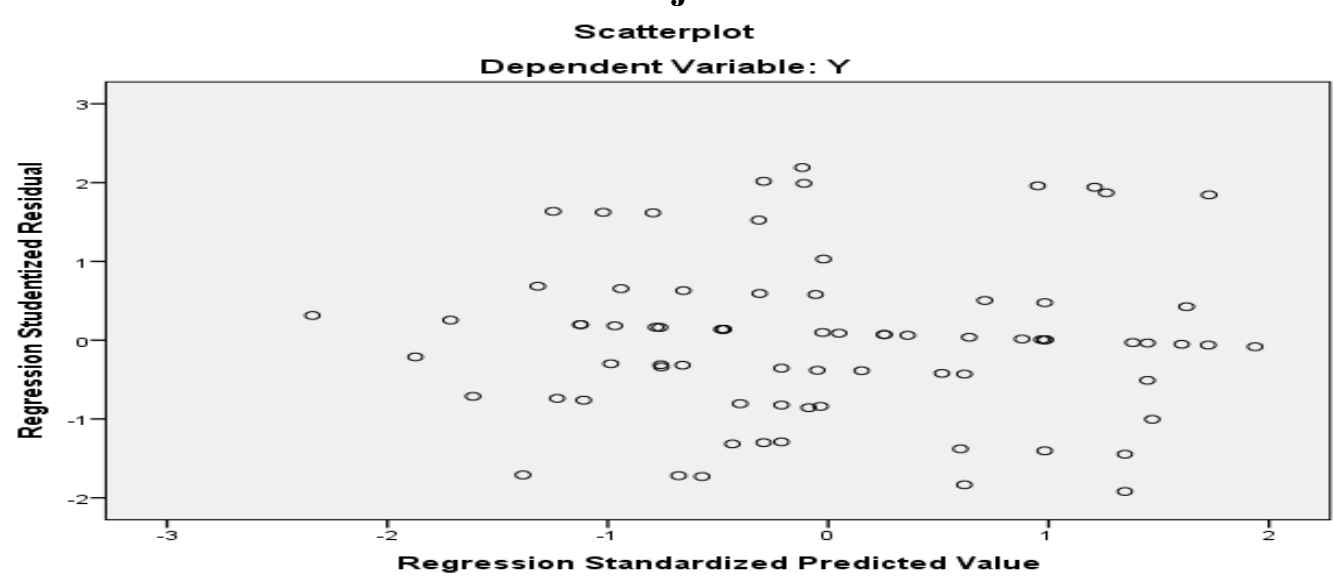

Sumber :Data Primer diolah, 2020 
Berdasarkan Gambar di atas dapat diketahui bahwa titik-titik dari data menyebar diatas, dibawah dan disekitar angka nol (0). Titik-titik tidak mengumpul hanya di atas atau di bawah saja. Penyebaran titik-titik data tidak membentuk pola bergelombang melebar kemudian menyempit dan melebar kembali dan penyebaran titik-titik data tidak berpola. Dengan demikian dapat disimpulkan bahwa data variabel kemudahan penggunaan, efektivitas dan resiko terhadap minat masyarakat mengajukan kredit di Fintech tidak terjadi masalah heteroskedastisitas, sehingga model regresi yang baik dan ideal dapat terpenuhi.

\section{Uji Normalitas}

Uji normalitas bertujuan untuk menguji apakah dalam model regresi variabel independen dan variabel dependen memiliki distribusi normal atau tidak. Pada prinsipnya normalitas data dapat diketahui dengan melihat penyebaran data (titik) pada sumbu diagonal pada grafik atau histogram dari residualnya. Dalam penelitian ini dapat juga dilakukan dengan Uji Kolmogrov-Smirnov, Test metode normal probability plots, dan metode histogram yang bertujuan untuk menguji apakah dalam model regresi, variabel residu memiliki distribusi normal/tidak. Pedomannya jika nilai Sig.< 0,05, maka data tidak berdistribusi normal dan sebaliknya Sig.> 0,05 maka data berdistribusi normal.

Tabel Hasil Uji Normalitas

One-Sample Kolmogorov-Smirnov Test
\begin{tabular}{|ll|r|}
\hline N & & Unstandardized Residual \\
Normal Parameters ${ }^{\mathrm{a}, \mathrm{b}}$ & Mean & 75 \\
& Std. Deviation &, 0000000 \\
Most Extreme Differences & Absolute & 1,09729592 \\
& Positive &, 124 \\
& Negative &, 124 \\
Test Statistic & &,- 078 \\
Asymp. Sig. (2-tailed) & &, 124 \\
\hline
\end{tabular}

a. Test distribution is Normal.

Berdasarkan tabel di atas, diketahui bahwa nilai signifikansi Asymp.sig (2tailed) sebesar 0,453 lebih besar dari 0,05. Maka sesuai dengan dasar pengambilan keputusan dalam uji normalitas kolmogorov-Smirnov dapat disimpulkan bahwa data berdistribusi normal. Dengan demikian, asumsi atau prasyaratan normalitas dalam model regresi sudah terpenuhi. Selain itu, pengujian ini juga dapat dilakukan secara visual dengan menggunakan Normal P-Plot. Dengan ketentuan dalam normal p-plot yaitu suatu variabel dikatakan normal jika titik-titik data menyebar disekitar garis diagonal dan penyebaran titik data searah mengikuti garis diagonal. 


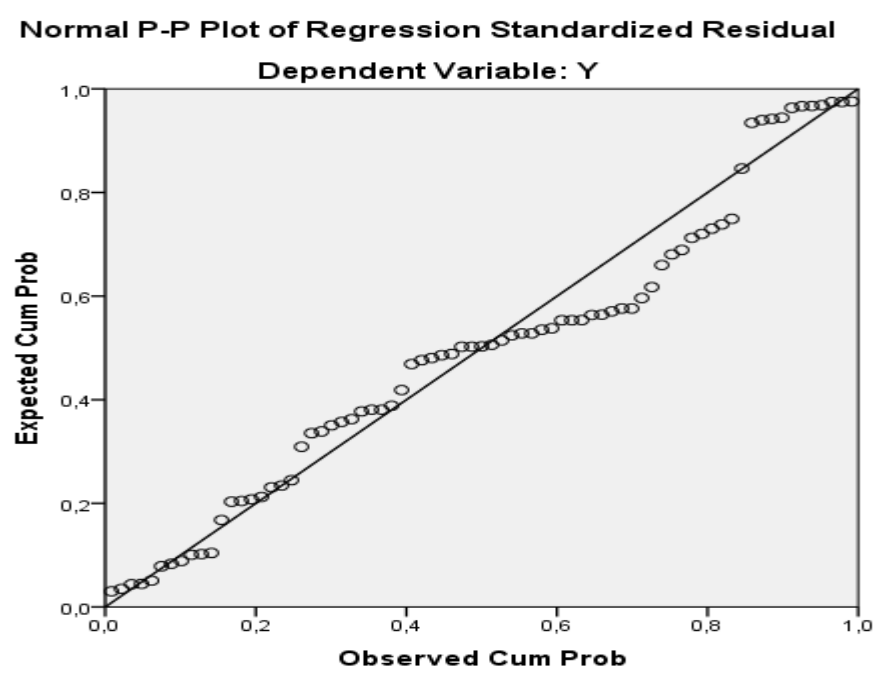

Sumber: Data Primer Diolah, 2020.

Berdasarkan gambar di atas menunjukkan bahwa data dari setiap observasi berada dekat dengan garis linear atau dapat dikatakan bahwa pola dari data mengikuti garis lurus regresi (diagonal). Maka dapat disimpulkan bahwa residual data berdistribusi normal. Selain uji kolmogorov-smirnov dan uji normal p-plot, dalam pengujian normalitas juga mengunakan metode histogram.

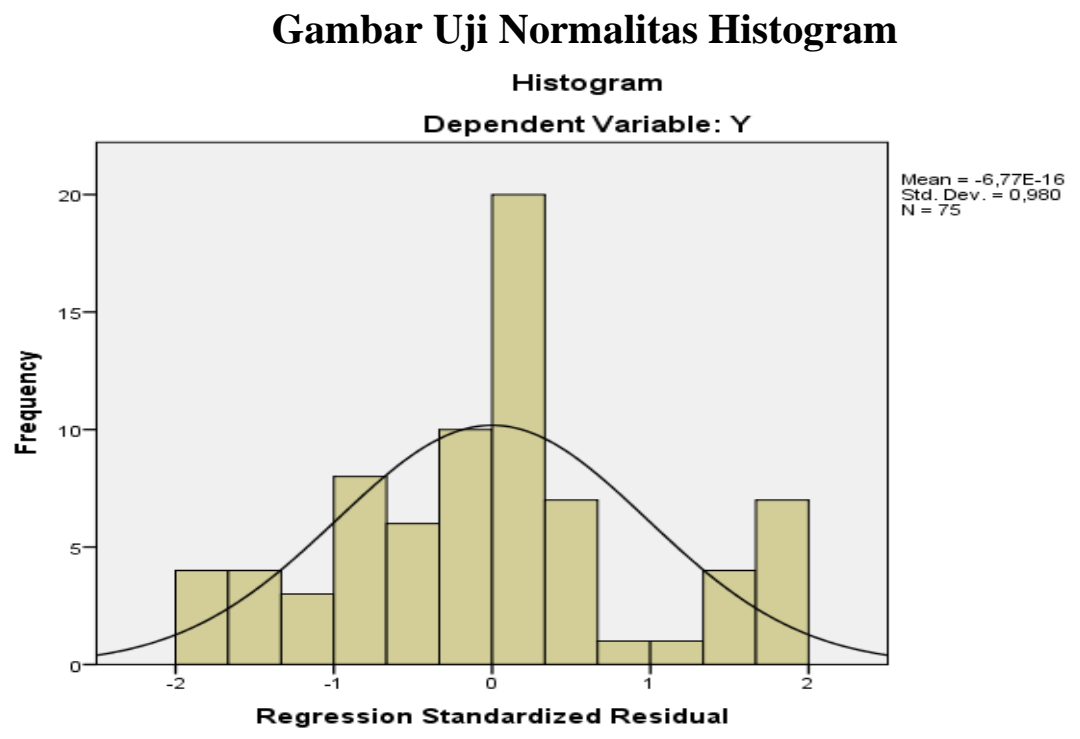

Sumber : Data primer diolah, 2020

Berdasarkan Gambar di atas, bentuk histogram memberikan pola yang seimbang/memiliki pola yang simetris, maka dapat disimpulkan bahwa data berdistribusi normal. Grafik ini menunjukkan bahwa model regresi sesuai dengan asumsi normalitas dan layak untuk digunakan.

\section{Uji Linearitas}

Uji linearitas dilakukan untuk mengetahui apakah antara variabel bebas dan variabel terikat mempunyai linear atau tidak. Dengan ketentuan jika koefisien signifikansi > 0,05 maka dapat dinyatakan bahwa garis regresi berbentuk linear.

\section{Tabel Uji Linearitas}


Kemudahan Penggunaan (X1) ANOVA Table

\begin{tabular}{|c|c|c|c|c|c|c|c|}
\hline & & & Sum of Squares & Df & $\begin{array}{l}\text { Mean } \\
\text { Square }\end{array}$ & $\mathrm{F}$ & Sig. \\
\hline \multirow{5}{*}{$\begin{array}{l}\text { Minat_masya } \\
\text { rakat* } \\
\text { Kemudahan_- } \\
\text { Penggunaan }\end{array}$} & \multirow{3}{*}{$\begin{array}{l}\text { Between } \\
\text { Groups }\end{array}$} & (Combined) & 17,651 & 5 & 3,530 & 3,469 &, 010 \\
\hline & & Linearity & 1,830 & 1 & 1,830 & 1,799 &, 187 \\
\hline & & $\begin{array}{l}\text { Deviation from } \\
\text { Linearity }\end{array}$ & 15,820 & 4 & 3,955 & 3,887 &, 109 \\
\hline & \multicolumn{2}{|c|}{ Within Groups } & 44,769 & 69 & 1,017 & & \\
\hline & \multicolumn{2}{|l|}{ Total } & 62,420 & 74 & & & \\
\hline
\end{tabular}

Berdasarkan nilai signifikansi (Sig) diperoleh nilai Deviation from Linearity variabel kemudahan penggunaan sebesar 0,109>0,05. Maka dapat disimpulkan bahwa terdapat hubungan linier secara signifikan antara variabel kemudahan penggunaan (X1) dengan variabel minat masyarakat mengajukan kredit di Fintech $(\mathrm{Y})$.

Efektivitas (X2)

ANOVA Table

\begin{tabular}{|l|l|l|r|r|r|r|r|}
\hline \multicolumn{2}{|c|}{} & $\begin{array}{c}\text { Sum of } \\
\text { Squares }\end{array}$ & df & $\begin{array}{c}\text { Mean } \\
\text { Square }\end{array}$ & \multicolumn{1}{c|}{ F } & \multicolumn{1}{c|}{ Sig. } \\
\hline $\begin{array}{l}\text { Minat_masy } \\
\text { arakat* } \\
\text { Efektivitas }\end{array}$ & $\begin{array}{l}\text { Between } \\
\text { Groups }\end{array}$ & (Combined) & 10,618 & 5 & 2,124 & 1,804 &, 132 \\
\cline { 2 - 8 } & Linearity & 1,822 & 1 & 1,822 & 1,548 &, 220 \\
\cline { 2 - 8 } & $\begin{array}{l}\text { Deviation from } \\
\text { Linearity }\end{array}$ & 8,796 & 4 & 2,199 & 1,868 &, 133 \\
\cline { 2 - 8 } & \multicolumn{2}{|l|}{ Within Groups } & 61,802 & 69 & 1,177 & & \\
\cline { 2 - 8 } & Total & 62,420 & 74 & & & \\
\hline
\end{tabular}

Berdasarkan nilai signifikansi (Sig) diperoleh nilai Deviation from Linearity variabel efektivitas sebesar 0,133>0,05. Maka dapat disimpulkan bahwa ada hubungan linier secara signifikan antara variabel efektivitas (X2) dengan variabel minat masyarakat mengajukan kredit di Fintech (Y).

Resiko (X3)

ANOVA Table

\begin{tabular}{|c|c|c|c|c|c|c|c|}
\hline & & & $\begin{array}{l}\text { Sum of } \\
\text { Squares }\end{array}$ & df & $\begin{array}{l}\text { Mean } \\
\text { Square }\end{array}$ & $\mathrm{F}$ & Sig. \\
\hline \multirow{5}{*}{$\begin{array}{l}\text { Minat_masya } \\
\text { rakat* } \\
\text { Resiko }\end{array}$} & \multirow{3}{*}{$\begin{array}{l}\text { Between } \\
\text { Groups }\end{array}$} & (Combined) & 4,029 & 5 &, 504 & ,354 &, 939 \\
\hline & & Linearity &, 053 & 1 &, 053 &, 037 & 848 \\
\hline & & $\begin{array}{l}\text { Deviation from } \\
\text { Linearity }\end{array}$ & 3,976 & 4 &, 568 & ,399 & ,898 \\
\hline & \multicolumn{2}{|c|}{ Within Groups } & 58,391 & 69 & 1,424 & & \\
\hline & \multicolumn{2}{|l|}{ Total } & 62,420 & 74 & & & \\
\hline
\end{tabular}

Berdasarkan nilai signifikansi (Sig) diperoleh nilai Deviation from Linearity variabel resiko sebesar 0,898 > 0,05. Maka dapat disimpulkan bahwa ada hubungan linier secara signifikan antara variabel resiko (X3) dengan variabel minat masyarakat mengajukan kredit di Fintech $(\mathrm{Y})$.

\section{Uji Autokorelasi}

Uji ini bertujuan untuk menguji apakah dalam sebuah model regresi linier ada korelasi antara kesalahan pengganggu dalam periode ke $\mathrm{t}$ dengan kesalahan pada periode ke t (sebelumnya). Adapun hasil uji Autokorelasi pada penelitian ini adalah sebagai berikut: 
Tabel Uji Autokorelasi

Model Summary ${ }^{\mathrm{b}}$

\begin{tabular}{|c|c|c|c|c|c|}
\hline Model & $\mathrm{R}$ & R Square & $\begin{array}{l}\text { Adjusted R } \\
\text { Square }\end{array}$ & $\begin{array}{l}\text { Std. Error of the } \\
\text { Estimate }\end{array}$ & Durbin-Watson \\
\hline &, $612^{\mathrm{a}}$ &, 374 &, 734 & 2,160 & 2,13 \\
\hline
\end{tabular}

a. Predictors: (Constant), X3, X1, X2

b. Dependent Variable: Y

Sumber: data primer diolah, 2020.

Berdasarkan tabel di atas menunjukkan bahwa nilai Durbin Watson sebesar 2,135 nilai ini menggunakan taraf signifikansi 5\% dengan jumlah sampel 75 (n) dan jumlah variabel independen tiga $(\mathrm{k}=3)$. Maka tabel Durbin Watson diperoleh nilai sebagai berikut.

Tabel 4.8

Durbin Watson Test Bound

\begin{tabular}{|c|c|c|}
\hline \multirow{2}{*}{$\mathrm{N}$} & \multicolumn{2}{|c|}{$\mathrm{k}=3$} \\
\cline { 2 - 3 } & $\mathrm{dL}$ & $\mathrm{dU}$ \\
\hline 75 & 1,5432 & 1,7092 \\
\hline
\end{tabular}

Sumber: data primer diolah, 2020

Berdasarkan tabel di atas menunjukkan bahwa dL sebesar 1,5432 dan dU sebesar 1,7092, maka jika dU 1,7092 < nilai Durbin Watson 2,135 < (4 - dU) 4 $1,7092=2,2908$. Hal ini menunjukkan bahwa tidak terdapat autokorelasi positif atau negatif dengan kriteria $\mathrm{dU}<\mathrm{d}<(4-\mathrm{dU})$. Maka model regresi pada penelitian ini tidak terjadi autokorelasi.

\section{C . Hasil Analisis Data}

\section{Analisis Regresi Berganda}

Analisis data yang digunakan adalah regresi linear berganda. Analisis regresi linear berganda merupakan sebuah teknik yang bertujuan untuk mengetahui hubungan dari satu/dua variabel bebas dan variabel terikat serta bagaimana variabel dependen dapat diprediksi melalui variabel independen secara simultan. Variabel yang diteliti yakni kemudahan penggunaan (X1), efektivitas (X2), resiko (X3) dan kemudahan penggunaan $(\mathrm{Y})$.

Tabel Uji Analisis Regresi Berganda

\begin{tabular}{|c|c|c|c|c|c|c|}
\hline \multicolumn{7}{|c|}{ Coefficientsa } \\
\hline \multirow{2}{*}{\multicolumn{2}{|c|}{ Model }} & \multicolumn{2}{|c|}{ Unstandardized Coefficients } & $\begin{array}{l}\text { Standardized } \\
\text { Coefficients } \\
\end{array}$ & \multirow[b]{2}{*}{$\mathrm{T}$} & \multirow[b]{2}{*}{ Sig. } \\
\hline & & $\mathrm{B}$ & Std. Error & Beta & & \\
\hline \multirow[t]{4}{*}{1} & (Constant) & 20,511 & 3,832 & & 5,353 & 000 \\
\hline & $\begin{array}{l}\text { Kemudahan_- } \\
\text { Penggunaan }\end{array}$ &, 569 &, 237 &, 560 & 2,506 & ,003 \\
\hline & Efektivitas & ,889 &, 247 & ,486 & 3,603 & ,002 \\
\hline & Resiko & ,836 & ,323 & ,742 & 2,296 & 004 \\
\hline
\end{tabular}

a. Dependent Variable: Y

Berdasarkan tabel Coefficients di atas memberikan informasi tentang persamaan regresi ada tidaknya pengaruh dari variabel kemudahan penggunaan, efektivitas dan 
resiko terhadap variabel minat masyarakat mengajukan kredit. Adapun rumus persamaan regresi dalam analisis penelitian ini adalah sebagai berikut;

\section{$Y=a+b 1 X 1+b 2 X 2+b 3 X 3$ atau $Y=20,511+0,569 X 1+0,889 X 2+0,836 X 3$}

Persamaan di atas dapat dijelaskan bahwa diperoleh nilai konstanta sebesar 20,511 yang mengandung arti bahwa nilai konstanta variabel minat sebesar 20,511. Koefisien regrasi variabel minat masyarakat melalui kemudahan penggunaan diperoleh nilai sebesar 0,569 Koefisien regresi variabel minat masyarakat melalui efektivitas diperoleh nilai sebesar 0,889 . Koefisien regresi variabel minat masyarakat melalui resiko diperoleh sebesar 0,836 .

\section{Pengujian Hipotesis}

Selanjutnya hasil dari persamaan regresi diinterpretasikan untuk mengetahui seberapa besar perubahan yang terjadi jika terjadi perubahan terhadap variabel terikat.

\section{Uji t (Uji Parsial)}

Uji parsial digunakan untuk menunjukkan sebarapa jauh satu variabel independen secara individu (parsial) dalam menerangkan variasi variabel dependen. Proses pengambilan kesimpulan adalah dengan melihat nilai signifikansi yang dibandingkan dengan nilai $\alpha(5 \%)$. Dimana hipotesis yang digunakan sebagai berikut:

Pengambilan keputusan berdasarkan nilai thitung:

1. Jika $t_{\text {hitung }}>t_{\text {tabel }}$ maka $\mathrm{H}_{0}$ ditolak $\mathrm{H}_{\mathrm{a}}$ diterima (signifikan).

2. Jika $t_{\text {hitung }}<t_{\text {tabel }}$ maka $\mathrm{H}_{0}$ ditolak $\mathrm{H}_{\mathrm{a}}$ ditolak (tidak signifikan).

Tabel Hasil Uji T

Coefficients $^{\mathbf{a}}$

\begin{tabular}{|c|c|c|c|c|c|c|}
\hline \multirow{2}{*}{\multicolumn{2}{|c|}{ Model }} & \multicolumn{2}{|c|}{ Unstandardized Coefficients } & \multirow{2}{*}{$\begin{array}{c}\begin{array}{c}\text { Standardized } \\
\text { Coefficients }\end{array} \\
\text { Beta }\end{array}$} & \multirow[b]{2}{*}{$\mathrm{T}$} & \multirow[b]{2}{*}{ Sig. } \\
\hline & & $\mathrm{B}$ & Std. Error & & & \\
\hline \multirow[t]{4}{*}{1} & (Constant) & 20,511 & 3,832 & & 5,353 &, 000 \\
\hline & $\begin{array}{l}\text { Kemudahan_- } \\
\text { Penggunaan }\end{array}$ &, 569 & ,237 &, 560 & 2,506 & ,003 \\
\hline & Efektivitas & 889 & ,247 & ,486 & 3,603 & ,002 \\
\hline & Resiko &, 836 & ,323 & ,742 & 2,296 & ,004 \\
\hline
\end{tabular}

a. Dependent Variable: Y

Berdasarkan tabel uji $\mathrm{t}$ di atas diketahui bahwa jumlah variabel pada penelitian ini adalah 3 yaitu kemudahan penggunaan, efektivitas dan resiko atau $\mathrm{K}=3$, Sementara jumlah sampel atau $\mathrm{N}=75$, maka $(\mathrm{N}-\mathrm{K}-1)=(75-3-1=71)$. Angka ini dilihat dari distribusi nilai $\mathrm{T}$ tabel maka diperoleh nilai $\mathrm{T}$ tabel adalah 1,993.

1. Nilai sig dari variabel kemudahan penggunaan yaitu $0.003<0.05$ (tingkat signifikansi), yang artinya bahwa pengaruh yang terjadi antara variabel kemudahan penggunaan dengan minat masyarakat mengajukan kredit di Fintech adalah signifikan secara statistik. Sedangkan nilai t hitung 2,506 >1,993 (t tabel), sehingga berpengaruh positif terhadap minat masyarakat mengajukan kredit di Fintech. Maka dapat disimpulkan bahwa pengaruh kemudahan penggunaan terhadap minat masyarakat mengajukan kredit di Fintech bersifat positif dan signifikan yaitu $\mathrm{H}_{0} 1$ ditolak dan $\mathrm{H}_{\mathrm{a}} 1$ diterima.

2. Nilai sig dari variabel efektivitas yaitu $0.002<0.05$ (tingkat signifikansi), yang artinya bahwa pengaruh yang terjadi antara variabel efektivitas dengan minat masyarakat mengajukan kredit di Fintech adalah signifikan secara statistik. Sedangkan nilai $\mathrm{t}$ hitung 3,603 >1,993 (t tabel), sehingga efektivitas 
berpengaruh positif terhadap minat masyarakat mengajukan kredit di Fintech. Maka, dapat disimpulkan pengaruh efektivitas terhadap minat masyarakat mengajukan kredit di Fintech bersifat positif dan signifikan yaitu $\mathrm{H}_{\mathrm{a}} 2$ diterima dan $\mathrm{H}_{0} 2$ ditolak.

3. Nilai sig dari variabel resiko yaitu $0.004<0.05$ (tingkat signifikansi), yang artinya bahwa pengaruh yang terjadi antara variabel resiko terhadap minat masyarakat mengajukan kredit di Fintech adalah signifikan secara statistik. Sedangkan nilai t hitung 2,296 >1,993 (t tabel), sehingga resiko berpengaruh positif terhadap minat masyarakat mengajukan kredit di Fintech. Maka, dapat disimpulkan bahwa pengaruh resiko terhadap minat masyarakat mengajukan kredit di Fintech bersifat positif dan signifikan yaitu $\mathrm{H}_{\mathrm{a}} 3$ diterima dan $\mathrm{H}_{0} 3$ ditolak.

\section{Uji Simultan ( Uji F )}

Uji simultan (F) bertujuan untuk mengetahui pengaruh semua variabel independen yaitu harga, kualitas dan pelayanan. Apabila nilai sig $<0,05$ atau $\mathrm{F}_{\text {hitung }}>$ $\mathrm{F}_{\text {tabel, }}$ maka model regresi signifikan secara statistik dapat disimpulkan bahwa $\mathrm{H}_{0}$ ditolak.

Tabel Hasil Uji Simultan (Uji F) ANOVA $^{\mathrm{a}}$

\begin{tabular}{|ll|r|r|r|r|r|}
\hline Model & & Sum of Squares & Df & Mean Square & F & Sig. \\
\hline 1 & Regression & 2,682 & 3 & 2,894 & 4,192 &, $000^{\mathrm{b}}$ \\
& Residual & 331,318 & 71 & 4,666 & & \\
& Total & 334,000 & 74 & & & \\
\hline
\end{tabular}

a. Dependent Variable: $Y$

b. Predictors: (Constant), X3, X1, X2

Berdasarkan hasil tabel uji $\mathrm{F}$ diatas diperoleh nilai sig sebesar $0.000<0,05$ (tingkat signifikan $\alpha$ ) dan $\mathrm{F}$ hitung sebesar 4,192 serta diketahui df1=k-1=3-1=2 dan df $2=\mathrm{N}-\mathrm{k}=75-3=72(\mathrm{~F}$ tabel= 3,12). Sehingga $\mathrm{F}$ hitung $>\mathrm{F}$ tabel $(4,192>3,12)$, maka $\mathrm{H}_{\mathrm{a}} 4$ diterima dan $\mathrm{H}_{0} 4$ ditolak yang artinya teradapat pengaruh signifikan antara variabel bebas terhadap variabel terikat. Jadi dapat disimpulkan bahwa kemudahan penggunaan, efektivitas dan resiko secara simultan berpengaruh signifikan terhadap minat masyarakat mengajukan kredit di Fintech.

\section{Uji Koefisien Determinasi $\left(\mathbf{R}^{\mathbf{2}}\right)$}

Koefisien determinasi yaitu nilai yang dapat mengukur besarnya pengaruh variabel bebas terhadap variabel terikat.

Tabel Hasil Uji Koefisien Determinasi $\left(\mathbf{R}^{2}\right)$

Model Summary

\begin{tabular}{|l|r|r|r|c|}
\hline Model & $\mathrm{R}$ & R Square & $\begin{array}{c}\text { Adjusted R } \\
\text { Square }\end{array}$ & $\begin{array}{c}\text { Std. Error of the } \\
\text { Estimate }\end{array}$ \\
\hline 1 &, $612^{\mathrm{a}}$ &, 374 &, 734 & 2,160 \\
\hline
\end{tabular}

a. Predictors: (Constant), X3, X1, X2

Berdasarkan Tabel di atas dapat diketahui bahwa hasil nilai dari Adjusted $R$ Square (adjusted $\mathrm{R}^{2}$ ) adalah sebesar 0,734. Nilai koefisien determinasi menunjukkan bahwa minat masyarakat mengajukan kredit di Fintech dipengaruhi sangat kuat oleh variabel kemudahan penggunaan (X1), efektiviitas (X2) dan resiko (X3) sebesar 73,4\%, 
sedangkan sisanya sebesar $(100 \%-73,4 \%=26,6 \%)$ dijelaskan oleh variabel lain yang tidak termasuk dalam penelitian ini.

\section{Pembahasan}

1. Kemudahan penggunaan berpengaruh terhadap minat masyarakat mengajukan kredit di Fintech

Hasil penelitian menunjukkan bahwa variabel kemudahan penggunaan berpengaruh positif terhadap minat masyarakat menajukan kredit di Fintech. Hal ini dibuktikan dari nilai sig variabel kemudahan penggunaan yakni $0.003<0.05$ (tingkat signifikansi), yang artinya bahwa pengaruh yang terjadi antara variabel kemudahan penggunaan dengan minat masyarakat menajukan kredit di Fintech adalah signifikan secara statistik. Sedangkan nilai t hitung t hitung 2,506 > 1,993 (t tabel), sehingga berpengaruh positif terhadap minat masyarakat mengajukan kredit di Fintech. Maka dapat disimpulkan pengaruh kemudahan penggunaan terhadap minat masyarakat menajukan kredit di Fintech bersifat positif dan signifikan yaitu $\mathrm{H}_{0} 1$ ditolak dan $\mathrm{H}_{\mathrm{a}} 1$ diterima.

Hasil penelitian ini sesuai dengan penelitian yang dilakukan oleh Veronica Yuniarti (2018) yang menyatakan bahwa kemudahan pengggunaan berpengaruh positif dan signifikan terhadap minat penggunaan Financial Technology. Hasil penelitian menunjukkan bahwa kemudahan penggunaan akan mempengaruhi minat masyarakat untuk menggunakan Fintech, karena dianggap lebih mudah dan tidak membutuhkan waktu yang lama. Namun hasil penelitian ini juga bertentangan dengan penelitian yang dilakukan oleh Khairul Firdausiyah (2016) yang menyatakan bahwa kemudahan penggunaan tidak berpengaruh positif dan signifikan terhadap kemudahan penggunaan.

2. Efektivitas berpengaruh terhadap minat masyarakat menajukan kredit di Fintech Hasil penelitian menunjukkan bahwa variabel efektivitas berpengaruh positif terhadap minat masyarakat mengajukan kredit di Fintech. Hal ini dibuktikan dengan nilai sig dari variabel efektivitas yakni $0.002<0.05$ (tingkat signifikansi), yang artinya bahwa pengaruh yang terjadi antara variabel efektivitas dengan minat masyarakat menajukan kredit di Fintech adalah signifikan secara statistik. Sedangkan nilai t hitung 3,603 > 1,993 (t tabel), sehingga kualitas berpengaruh positif terhadap minat beli. Maka, dapat disimpulkan pengaruh variabel efektivitas terhadap minat masyarakat mengajukan kredit di Fintech bersifat positif dan signifikan yaitu $\mathrm{H}_{\mathrm{a}} 2$ diterima dan $\mathrm{H}_{0} 2$ ditolak.

Hasil penelitian ini sesuai dengan penelitian yang dilakukan oleh Luhdrini Nilamtiti Dampararas (2017) yang menyatakan bahwa efektivitas berpengaruh positif dan signifikan terhadap minat penggunaan Financial Technology. Hasil penelitian menunjukkan bahwa efektivitas mempengaruhi minat masyarakat untuk menggunakan Fintech, karena dianggap lebih efektif untuk memperoleh pinjaman dengan waktu yang cepat. Namun hasil penelitian ini juga bertentangan dengan penelitian yang dilakukan oleh Lina Apriani (2017) yang menyatakan bahwa efektivitas tidak berpengaruh positif dan signifikan terhadap minat masyarakat mengajukan kredit di Fintech.

3. Resiko berpengaruh terhadap minat masyarakat mengajukan kredit di Fintech 
Hasil penelitian menunjukkan bahwa variabel resiko berpengaruh positif terhadap minat masyarakat mengajukan kredit di Fintech. Hal ini dibuktikan dari nilai sig dari variabel resiko yakni $0.004<0.05$ (tingkat signifikansi), yang artinya bahwa pengaruh yang terjadi antara variabel resiko dengan minat masyarakat menajukan kredit di Fintech adalah signifikan secara statistik. Sedangkan nilai t hitung 2,296 >1,993 (t tabel), sehingga variabel resiko berpengaruh positif terhadapminat beli. Maka, dapat disimpulkan bahwa pengaruh resiko terhadap minat masyarakat mengajukan kredit di Fintech bersifat positif dan signifikan yaitu $\mathrm{H}_{\mathrm{a}} 3$ diterima dan $\mathrm{H}_{0} 3$ ditolak.

Hasil penelitian ini sesuai dengan penelitian yang dilakukan oleh Muhammad Wildan (2019) yang menyatakan bahwa resiko berpengaruh positif dan signifikan terhadap minat penggunaan Financial Technology. Hasil penelitian menunjukkan bahwa resiko mempengaruhi minat masyarakat untuk menggunakan Fintech, karena dianggap resiko dalam menggunakan fintech sangat tinggi terutama dalam keamanan data. Namun hasil penelitian ini juga bertentangan dengan penelitian yang dilakukan oleh Yulia Agustina (2018) yang menyatakan bahwa resiko tidak berpengaruh positif dan signifikan terhadap minat masyarakat mengajukan kredit di Fintech.

4. Kemudahan Penggunaan, efektivitas dan resiko berpengaruh secara Simultan terhadap masyarakat mengajukan kredit di Fintech

Hasil penelitian menunjukkan bahwa nilai sig sebesar $0.000<0,05$ (tingkat signifikan $\alpha$ ) dan $\mathrm{F}$ hitung sebesar 4,889 serta diketahui df1=k-1=3-1=2 dan df2= $\mathrm{N}-\mathrm{k}=75-3=72\left(\mathrm{~F}\right.$ tabel= 3,12). Sehingga $\mathrm{F}$ hitung $>\mathrm{F}$ tabel $(4,192>3,12)$, maka $\mathrm{H}_{\mathrm{a}} 4$ diterima dan $\mathrm{H}_{0} 4$ ditolak yang artinya teradapat pengaruh signifikan antara variabel bebas terhadap variabel terikat. Maka, dapat disimpulkan bahwa kemudahan penggunaan, efektivitas dan resiko berpengaruh secara simultan terhadap minat masyarakat mengajukan kredit di Fintech.

\section{KESIMPULAN}

Berdasarkan hasil analisa data-data hasil penelitian pada penelitian ini, maka dapat peneliti simpulkan hasil penelitian ini adalah sebagai berikut:

1. Secara parsial kemudahan penggunaan berpengaruh positif dan signifikan terhadap minat masyarakat mengajukan kredit di Fintech dengan nilai t hitung 2,506 > 1,993 (t tabel) dan nilai sig $0.003<0.05$.

2. Secara parsial efektivitas berpengaruh positif dan signifikan terhadap minat masyarakat mengajukan kredit di Fintech dengan nilai t hitung 3,603 > 1,993 (t tabel) dan nilai sig $0.002<0.05$.

3. Secara parsial resiko berpengaruh positif dan signifikan terhadap minat masyarakat mengajukan kredit di Fintech dengan nilai t hitung 2,296 >1,993 (t tabel) dan nilai $0.004<0.05$.

4. Secara simultan kemudahan penggunaan, efektivitas dan resiko secara simultan berpengaruh terhadap positif dan signifikan terhadap minat masyarakat mengajukan kredit di Fintech. Hal ini dibuktikan dari nilai $\mathrm{F}$ hitung > F tabel $(4,192>3,12)$ dan nilai signifikan sebesar 0,000, maka sebagaimana dasar pengambilan keputusan dalam uji $\mathrm{F}$ dapat disimpulkan bahwa hipotesis diterima.

\section{DAFTAR PUSTAKA}


Ahmadi, Rulam. 2005. Memahami Metodologi Penelitian Kualitatif. Malang: Universitas Negeri Malang.

Akmaltarigan, Azhari. 2013. Pedoman Penulisan Proposal dan Skripsi Ekonomi Islam. Medan:Wal Ashri Publishing.

Arikunto, Suharsimi. 2010. Prosedur Penelitian, suatu Pendekatan Praktek. Jakarta: Rineka Cipta.

Ary, et.al. 2000. Pengantar Penelitian dalam Pendidikan. Surabaya:Usaha Nasional.

Asosiasi penyelenggara jasa Internet Indonesia, "survey: penetrasi dan perilaku penggunaInternet",2017.Diakses Pada tanggal 27 Januari 2020.

Bank Indonesia, Surat edaran No.18/22/DKSP. Penyelenggaraan Layanan Keuangan Digital, 2016.

Bimo, Walgito. 2008. Pengantar Psikologi Umum. Yogyakarta: Yayasan Penertbitan Fakultas Psikologi UGM.

Bungin, Burhan. 2005. Metodologi Penelitian Kuantitatif Komunikasi, Ekonomi dan Kebijakan Publik Ilmu-ilmu Sosial lainnya. Kencana: Jakarta.

Douglas Arner, Et.al. 2015. The Evolution of Fintech: A new Post-crisisParadigm?, Research Paper No.2015/047, University of HongKong Facultyof Law.

Ghozali, Imam. 2005. Aplikasi Analisis Multivariate dengan Program SPSS. Semarang: Badan Penerbit UNDIP.

Douglas Arner, Et.al. 2015. The Evolution of Fintech: A new Post-crisisParadigm?, Research Paper No.2015/047, University of HongKong Facultyof Law.

Financial Stability Board. Financial Stability Implications from Fintech: Supervisory and Regulatory Issues that Merit Authorities Attention. Diakses pada tanggal 27Januari 2020.Pukul: 09.00 WIB.

Harlan, Dwimastia. 2014. Pengaruh Kemudahan Penggunaan, Kepercayaan dan Risiko Persepsian terhadap Minat Bertransaksi menggunakan E-banking pada UMKM di Kota Yogyakarta. Skripsi, FEUNY.

Husein, Umar. 2010. Manajemen Riset Pemasaran dan Perilaku Konsumen, Jakarta: PT Gramedia Pusaka.

Irmadhani dan Mahendra Adi Nugroho. 2012. Pengaruh Kemudahan Penggunaan dan Computer Self Efficacy Terhadap Penggunaan Online Banking Pada Mahasiswa S1Fakultas Ekonomi Universitas Negeri Yogyakarta. Jurnal FEUNY,Vol.1 No.3.

Istiarni, Panggih Dwi. 2014. Analisis Pengaruh Pespsi Manfaat, Kemudahan Penggunaan dan Kredibiltas terhadap Minat Penggunaan Berulang Internet Banking dengan Sikap penggunaan Sebagai Varibel Intervening. Skripsi FEBUNDIP Semarang.

Karim, Mustofa Abdul. 2017. Pengaruh Sistem Pembayaran Go-pay Menggunakan TAM (Technology Acceptence Model) Terhadap Intensitas Penggunaan Layanan Gojek.Skripsi FEUII.

Lexy.J.Moleong. 2006. Metode Penelittian Kualitatif (edisi revisi). PT Remaja Rosdakarya Offset: Bandung.

Magda, Kardita. 2017. Pengaruh Kualitas Produk, Harga, dan Lokasi Terhadap Keputusan Pembelia, Bandar Lampung: Universitas Lampung.

Meiliyah Ariani dan Zulhawati. 2017. Pengaruh Kualitas Layanan, Keamanan dan Risiko Terhadap Minat Menggunakan LinePay. Jurnal, Conferenceon Management and Behavioral Studies,Universias Tarumanegara, Jakarta.ISSN No.2541-3406,e-ISSNNo.2541. 
Mulyana, Yusuf Fitra. 2016. Pengaruh Kepercayaan, Persepsi Risiko dan Keamanan Terhadap Minat Beli Konsumen Pada Toko Online. Skripsi. Semarang. FEUNDIP. Murdwiyanto, Embun Fathia. 2018. Faktor-Faktor yang Mempengaruhi Keputusan UMKM dalam Mengambil Pinjaman Melalui Peer-To-Peer (P2P) Lending. Institut Pertanian Bogor.

Nizar, Muhammad Afdi. 2017. Teknologi Keuangan: Konsep dan Implementasinya di Indonesia. Warta Fiskal Edisi V, Kementrian Keuangan.

Paul A. Pavlou, 2010. Consumer Acceptance of Electronic Commerce: Integrating, Trustand Risk with the Technology Acceptance Model'. International journal of Electronic Commerce, Vol.7.

Prasiska, Yulia. 2019. Pengaruh Financial Technology (FINTECH) terhadap Profitabilitas Perbankan Syariah. UIN Raden Intan Lampung.

Saadah, Naili. 2018. Perencanaan Keuangan Islam Sederhana dalam Bisnis ECommerce pada Pengguna OnlineShop'..Economica:Jurnal Ekonomi Islam.Volume.9 No.1.

Sari, Fitri Ratna. 2014. Analisis Faktor-Faktor yang Mempengaruhi Keputusan Nasabah dalam Mengambil Kredit. Universitas Muhammadiyah Surakarta.

Sudjana. 2011. Metode Statistika. Bandung: Tarsito.

Sugiono. 2010. Metode Penelitian Pendidikan: Pendekatan Kuantitatif, dan Pendekatan Kualitatif. Bandung: Alfabeta.

Suryabrata, Sumadi. 2009. Psikologi Pendidikan. Jakarta: PT.Grafindo Perkasa Rajawali.

Svetlana Saksonova dan Irina Kusmina Marlino. 2017. Fintech as Financial Inovationthe possibilities and problems of Implementation. European studies research journal, vol.XX, issue $3 A$.

Sudjana. 2011. Metode Statistika. Bandung: Tarsito.

Sugiyono. 2006. Metode Penelitian Administrasi. Bandung: Alfabeta,

Sugiyono. 2010. Metodologi Penelitian Bisnis. Bandung: Alfabeta,

Umar, Husein. 2003. Metode Riset bisnis. Jakarta: PT. Gramedia Pustaka Utama.

Widhiarsa, Okto. 2011. Analisis Tingkat Kepuasan Konsumen Terhadap Kualitas Pelayanan Hotel. (Studi Kasus pada Hotel Ciputra di Semarang.

Wijawanti, Titik. 2018. Pelaksanaan Pemberian Kredit Berbasis Teknologi Informasi oleh FINTECH Kepada Pelaku UMKM. Universitas Muhammadiyah Surakarta.

https://Fintech.id. di akses pada tanggal 26 Januari 2020. Pukul: $13.30 \mathrm{WIB}$

https://Fintech.iddiakses pada tanggal 26 Januari 2020. Pukul: 14.00 WIB 